\title{
Efficacy of Oral Antigen Specific Immunotherapy on Desensitization of Some Autoimmune Diseases Associated with Milk Allergy
}

\author{
Azza A. Atef ${ }^{1}$, Mohamed Y. Attia ${ }^{2}$, Osama E. Abdel Aal ${ }^{1}$ \\ ${ }^{1}$ Biochemistry Department, Faculty of Science, Ain Shams University, Cairo, Egypt; ${ }^{2}$ Allergy \& Immunology Unit, Ain Shams Uni- \\ versity Hospitals, Cairo, Egypt. \\ Email: mohamedyousef91@yahoo.com
}

Received May $19^{\text {th }}, 2012$; revised January $2^{\text {nd }}, 2013$; accepted January $9^{\text {th }}, 2013$

Copyright (C) 2013 Azza A. Atef et al. This is an open access article distributed under the Creative Commons Attribution License, which permits unrestricted use, distribution, and reproduction in any medium, provided the original work is properly cited.

\begin{abstract}
There are several reports on the prevalence and importance of milk allergens in the induction of allergic diseases, whereas its role in the induction of autoimmune disease was rarely studied. So, the present work aimed to study the diagnosis and the efficacy of oral antigen specific immunotherapy (OAIT) on two groups of autoimmune disease patients namely, rheumatic arthritis (RA), group II, and systemic lupus erythematosus (SLE), group III, who has allergens for milk as an effective treatment option. From the assessment of the data obtained and the clinical outcome of RA and SLE patients after food elimination strategy and milk immunotherapy, it was evident that there were significant reductions $(P$ $<0.001$ ) in the levels of total IgE, specific IgE, Rheumatic factor (R.F), C-reactive protein (C.R.P), Anti-nuclear antibodies (ANA) and anti-double stranded DNA antibodies (Anti-ds DNA) compared to pretreated levels. Moreover, the immunotherapy induced "blocking antibodies" by remarkable highly significant increasing in IgG, phagocytic inhibition test (PIT \%), Complement component 3(C3), and Complement component 4 (C4) levels. More improvement was noticed in the SLE as a result of the immunotherapy. Conclusion: milk desensitization is a gained interest and a safe valuable effective treatment of autoimmune conditions in Egypt.
\end{abstract}

Keywords: Immunotherapy; Milk Allergy; Autoimmune Diseases

\section{Introduction}

Food allergy described as adverse immune responses was triggered by food proteins, which affect approximately $5 \%$ of young children and 3\% to $4 \%$ of adults in the world and appear to have increased in prevalence and account for morbidity and mortality $[1,2]$.

Cow's milk is usually the first major food allergy with a prevalence ranging from 1 to about $7.5 \%$ [3]. The most important allergens in cow's milk are $\alpha$-lactalbumin, $\beta$-lactoglobulin, and casein [4]. Food-induced allergic reactions are responsible for a variety of symptoms and disorders involving the skin and gastrointestinal and respiratory tracts and can be attributed to IgE-mediated and non-IgE-mediated mechanisms $[2,5]$.

A food elimination/challenge trial is a good and reliable way to confirm diagnosis of food allergy [6,7]. Research into the use of oral antigen-specific immunotherapy (OAIT) in the treatment of both allergic and autoimmune disease has increased dramatically since, although its mechanism of action is only slowly being unraveled. The treatment by OAIT makes tolerance for the disease and used for both allergic and autoimmune diseases [8].

Association between adult rheumatoid arthritis (RA) and milk allergy has previously been reported [9] additionally; previous studies demonstrated that milk allergy may induce rheumatoid arthritis [10].

Systemic lupus erythematosus (SLE) is the prototype of a systemic autoimmune disease and is characterized by the presence of multiple autoantibodies and circulating immune complexes. Especially antibodies to dsDNA (anti DNA) are specific for the disease, and changes in their levels are a sensitive tool for the detection of disease activity $[11,12]$.

The present work aimed to clarify the validity of oral immunotherapy and milk elimination treatment interventions in patients with RA and SLE who had allergens for milk. In addition, the correlation between specific $\operatorname{IgE}$ and milk allergy, inflammation and disease markers has 
been investigated.

\section{Subjects and Methods}

\subsection{Subjects}

Twenty normal subjects ( 10 males and 10 females) their age ranged from $16-46(30.0 \pm 7.78)$ and 40 age matched allergic patients of both genders (12 males and 28 females) were included in this study. The patients were diagnosed as RA with milk allergy and SLE with milk allergy. The patients were selected out from the patients of the Allergy and Clinical Immunology Clinic at Ain Shams hospitals. They were surveyed throughout a period of three-years (2009-2012).

\subsection{Written Consents}

Discussion with the subjects regarding the benefits and hazards of the study was done and informed written consent was taken from each subject.

\subsection{Study Groups}

Group I: 20 normal control subjects. Group II: 20 rheumatic arthritis (RA) patients Group III: 20 systemic lupus erythematosus (SLE) patients.

\subsection{Clinical Studies and Routine Investigations}

For each subject, the following investigations were conducted to exclude any concomitant disease that might cause allergy. a) Full data regarding family medical history, habitat, work place, duration of attack, and economic status; b) Physical examinations by an expert physician in the clinic; c) Urine and stool analysis, kidney and liver function tests, blood sugar analysis, and X-Ray examination.

\subsection{Diagnostic Laboratory Investigations}

Skin prick test, total IgE, Sp. IgE Milk, PIT\%, CRP, ANA, DNA antibodies, IgG, C3 and C4.

\subsection{Immunotherapy Treatment Technique}

It was done according to $[13,14]$.

Milk and its products were eliminated from patients' diet throughout the period of milk vaccine treatment (6 months). All pervious investigations were being done before and after elimination and therapy. Blood samples were taken with or without anticoagulant for separation of whole blood and serum samples respectively from normal subjects as well as from patients.

\subsection{Methods}

Skin prick test: To confirm allergy to milk. Epicutaneous prick method was done using milk extracts according to [15]. Specific IgE test for milk: It was done for patients with positive skin prick test for milk according to the instruction of the manufacture of Micro plate Allergen specific IgE, RIDA SCREEN Spezifisches IgE, Germany $[16,17]$. Serum total IgE: Total IgE concentration was determined by using microplate enzyme immunoassay (Biocheck, Inc. 323 Vintage Park Dr. Foster City, CA 94404, USA) according to the method of [18]. Serum $I g G$ : It was measured using immunodiffusion (Bioscientifica S.A Company) according to the method of [19]. Serum $R F$ : it was done according to the methods of [20] using Human Gesellschaft fur, Biochemica und Diagnostica kit (mbH, D-65205 Wiesbaden-Germany). Serum CRP: It was determined according to the method of [21] using AGAPPE diagnostics Ltd. kit, (Dist. Emakulam, Kerala-683 562, India). PIT\%: This test allows the quantitative determination of leukocyte phagocytosis in buffy coat of heparinized blood. It depends on histamine inhibition to phagocytes [22]. ANA and anti-ds DNA: ANAs in patient samples were assessed by commercial ANA assays in accordance with the instructions of the manufacturer of Euroimmun, Medizinische Labor-diagnostika, (AG, 23560, Lübeck, Germany) and for anti-dsDNA of Euroimmun, Mediz-inische, Labor-diagnostika (AG, 23,560, Lübek, Germany) according to the method of [23]. $C 3$ and $C 4$ : Radial Immuno diffusion for the accurate quantitative determination of $\mathrm{C} 3$ and $\mathrm{C} 4$ in serum was done according to [24] using Bioscientifica S.A. Statistical analysis: Data were analyzed using the SPSS program Version 15 as follows: $p$ value 0.05 was chosen as the level of statistical significance. $p$ value $>0.05$ is insignificant; $p$ value $<0.05$ is significant; $p$ value $<0.01$ is highly significant.

\section{Results}

Results in Table 1 showed that in RA group and SLE group as compared to the control group, pretreatment serum levels of $\mathrm{Sp}$. $\mathrm{IgE}$ and total $\mathrm{IgE}$ were significantly increased $(p<0.001)$ with \% change values for RA group 300.74 and $255.58 \&$ for SLE group 291.34 and 235.23 while serum levels of IgG and PIT\% were significantly decreased $(p<0.001)$ with $\%$ change values for RA group -26.43 and $-32.53 \&$ for SLE group -34.26 and -33.39 . On the other hand as compared to the post treatment serum levels, Sp.IgE and total $\mathrm{IgE}$ were significantly decreased $(p<0.001)$ with $\%$ change values for RA group -30.26 and $-42.58 \&$ for SLE group -50.00 and -49.93 while serum levels of IgG and PIT\% were significantly increased $(p<0.001)$ with $\%$ change values for RA group 77.56 and $31.63 \&$ for SLE group 98.28 and 31.52 .

Results in Table 2 showed that in RA group and SLE group as compared to the control group, pretreatment 
Table 1. Levels of Sp. IgE, Total IgE, IgG, and PIT in the different studied groups.

\begin{tabular}{|c|c|c|c|c|}
\hline$\underbrace{\text { Parameters }}_{\text {Groups }}$ & $\begin{array}{c}\text { Serum } \\
\text { Sp. IgE Milk } \\
\text { IU } / \mathrm{ml}\end{array}$ & $\begin{array}{l}\text { Serum } \\
\text { Total IgE } \\
\text { IU/ml }\end{array}$ & $\begin{array}{c}\text { Serum } \\
\text { IgG } \\
\mathrm{mg} / \mathrm{dl}\end{array}$ & $\begin{array}{l}\text { PIT } \\
\%\end{array}$ \\
\hline \multicolumn{5}{|l|}{ GroupI(control) } \\
\hline mean $\pm \mathrm{SD}$ & $0.19 \pm 0.05$ & $22.85 \pm 7.15$ & $1147.00 \pm 115.66$ & $29.05 \pm 1.76$ \\
\hline Range & $(0.10-0.27)$ & $(10.00-40.00)$ & $(959.00-1345.00)$ & $(27.00-33.00)$ \\
\hline \multicolumn{5}{|l|}{$\begin{array}{l}\text { Group II RA } \\
\text { Before therapy }\end{array}$} \\
\hline mean $\pm \mathrm{SD}$ & $0.76 \pm 0.25^{\mathrm{a}}$ & $81.25 \pm 18.88^{\mathrm{a}}$ & $843.80 \pm 162.60^{\mathrm{a}}$ & $19.60 \pm 2.50^{\mathrm{a}}$ \\
\hline Range & $(0.51-1.42)$ & $(60.00-124.00)$ & $(512.00-1120.00)$ & $(17.00-23.00)$ \\
\hline${ }^{*} \%$ Change & $300.74 \mathbf{4}$ & $255.58 \boldsymbol{4}$ & $-26.43 \downarrow$ & $-32.53 \downarrow$ \\
\hline \multicolumn{5}{|l|}{ After therapy } \\
\hline mean $\pm \mathrm{SD}$ & $0.35 \pm 0.04^{\mathrm{ab}}$ & $45.65 \pm 18.48^{\mathrm{ab}}$ & $1498.30 \pm 162.06^{\mathrm{ab}}$ & $25.80 \pm 1.85^{\mathrm{ab}}$ \\
\hline Range & $(0.30-0.48)$ & $(26.00-92.00)$ & $(1190.00-1780.00)$ & $(23.00-28.00)$ \\
\hline$\%$ \% Change & $85.26 \mathbf{4}$ & $99.78 \mathbf{4}$ & $30.63 \boldsymbol{4}$ & $-11.19 \downarrow$ \\
\hline${ }^{* *} \%$ Change & $-30.26 \downarrow$ & $-42.58 \downarrow$ & $77.56 \mathbf{4}$ & $31.63 \mathbf{4}$ \\
\hline \multicolumn{5}{|l|}{$\begin{array}{l}\text { Group III SLE } \\
\text { Before therapy }\end{array}$} \\
\hline mean $\pm \mathrm{SD}$ & $0.74 \pm 0.16^{\mathrm{a}}$ & $76.60 \pm 15.06^{\mathrm{a}}$ & $754.05 \pm 123.07^{\mathrm{a}}$ & $19.35 \pm 1.73^{\mathrm{a}}$ \\
\hline Range & $(0.57-1.12)$ & $(62.00-117.00)$ & $(510.00-912.00)$ & $(17.00-22.00)$ \\
\hline${ }^{*} \%$ Change & 291.34 ㅅ & 235.23 个 & $-34.26 \downarrow$ & $-33.39 \downarrow$ \\
\hline \multicolumn{5}{|l|}{ After therapy } \\
\hline mean $\pm \mathrm{SD}$ & $0.37 \pm 0.07^{\mathrm{ab}}$ & $38.35 \pm 9.72^{\mathrm{ab}}$ & $1495.20 \pm 198.10^{\mathrm{ab}}$ & $25.45 \pm 1.50^{\mathrm{ab}}$ \\
\hline Range & $(0.29-0.57)$ & $(29.00-72.00)$ & $(1140.00-1870.00)$ & $(23.00-29.00)$ \\
\hline${ }^{*} \%$ Change & $94.47 \boldsymbol{4}$ & $67.83 \boldsymbol{4}$ & $30.36 \boldsymbol{1}$ & $-12.39 \boldsymbol{4}$ \\
\hline${ }^{* *} \%$ Change & $-50.00 \downarrow$ & $-49.93 \downarrow$ & $98.28 \boldsymbol{\uparrow}$ & $31.52 \boldsymbol{\uparrow}$ \\
\hline
\end{tabular}

Each value is considered statistically significant at $p<0.001 .{ }^{*} \%$ Change from control group; ${ }^{* *} \%$ Change from untreated groups; ${ }^{a}$ Patients groups significantly different from control group; ${ }^{b}$ Patients groups before treatment significantly different from after immunotherapy.

serum levels of RF, CRP, ANA and anti-ds DNA were significantly increased $(p<0.001)$ with $\%$ change values for RA group $1170.23,771.79,110.53,102.21 \&$ for SLE group 171.43, 833.33, 952.63, 877.27.Serum levels of C3 was significantly decreased $(p<0.001)$ in RA group with \% change values -29.91 while both $\mathrm{C} 3$ and C4 levels were significantly decreased in SLE group (\% change: -67.51 and -55.50$)$. On the other hand as compared to the post treatment serum levels, RF, CRP, ANA, anti-ds DNA were significantly decreased $(p<0.001)$ with \% change values for RA group $-65.52,-65.05$, $-25.62,-13.45 \&$ for SLE group $-5.26,-62.30,-58.75$, -66.57. Whereas serum levels of $\mathrm{C} 3$ and $\mathrm{C} 4$ were significantly increased $p<0.001$ with $\%$ change values for
RA group 20.57 and $12.39 \&$ for SLE group 102.24 and 64.26.

Results in Table 3 showed there was a good correlations between $\mathrm{Sp}$. IgE and each parameter in the different studied groups.

\section{Discussion}

In the current study (Table 1) the significant increase in the levels of $\mathrm{Sp}$. IgE and total $\mathrm{IgE}$ in RA patient group before OAIT as compared to the control values confirmed diagnosis of milk allergen and the severity of allergy due to milk allergen. This agreed with the results of some authors [2,25] and supported by others [26] 
Table 2. Levels of RF, CRP, ANA, anti DNA, C3 and C4 in the different studied groups.

\begin{tabular}{|c|c|c|c|c|c|c|}
\hline $\begin{array}{l}\text { Parameters } \\
\text { Groups }\end{array}$ & $\begin{array}{c}\text { Serum RF } \\
\text { IU/ml }\end{array}$ & $\begin{array}{c}\text { Serum CRP } \\
\text { mg/dl }\end{array}$ & $\begin{array}{c}\text { Serum ANA } \\
\text { IU/ml }\end{array}$ & $\begin{array}{c}\text { Serum anti-ds DNA } \\
\text { IU/ml }\end{array}$ & $\begin{array}{c}\text { Serum C3 } \\
\text { mg/dl }\end{array}$ & $\begin{array}{c}\text { Serum C4 } \\
\text { mg/dl }\end{array}$ \\
\hline \multicolumn{7}{|l|}{ Group I } \\
\hline mean $\pm \mathrm{SD}$ & $4.20 \pm 2.33$ & $1.95 \pm 1.23$ & $3.80 \pm 1.51$ & $6.80 \pm 2.63$ & $116.50 \pm 14.8$ & $32.7 \pm 5.59$ \\
\hline Range & $(2.00-8.00)$ & $(0.00-4.00)$ & $(2.00-6.00)$ & $(2.00-12.00)$ & $(89.00-140.00)$ & $(25.00-42.0)$ \\
\hline \multicolumn{7}{|l|}{$\begin{array}{c}\text { Group II RA } \\
\text { Before treatment }\end{array}$} \\
\hline mean \pm SD & $53.35 \pm 23.23^{\mathrm{a}}$ & $17.0 \pm 8.95^{\mathrm{a}}$ & $8.00 \pm 1.12^{\mathrm{a}}$ & $13.75 \pm 2.71^{\mathrm{a}}$ & $81.65 \pm 10.47^{\mathrm{a}}$ & $30.30 \pm 5.87$ \\
\hline Range & $(24.0-80.0)$ & $(6.0-32.0)$ & $(6.0-10.0)$ & $(10.0-20.0)$ & $(60.0-105.0)$ & $(20.0-40.0)$ \\
\hline "\% Change & 1170.24 个 & $771.79 \boldsymbol{\mathbf { A }}$ & $110.53 \mathbf{4}$ & $102.21 \boldsymbol{4}$ & $-29.91 \downarrow$ & $-7.33 \downarrow$ \\
\hline \multicolumn{7}{|l|}{ After treatment } \\
\hline mean \pm SD & $19.10 \pm 7.96^{\mathrm{ab}}$ & $6.50 \pm 2.50^{\mathrm{ab}}$ & $5.95 \pm 1.15^{\mathrm{ab}}$ & $11.90 \pm 5.89^{\mathrm{ab}}$ & $98.45 \pm 17.18^{\mathrm{ab}}$ & $36.75 \pm 4.75^{\mathrm{b}}$ \\
\hline Range & $(6.00-35.0)$ & $(4.00-12.00)$ & $(4.00-8.00)$ & $(6.00-30.00)$ & $(60.00-127.00)$ & $(26.00-43.00)$ \\
\hline *\% Change & $353.57 \mathbf{4}$ & $233.33 \mathbf{4}$ & $56.58 \boldsymbol{\top}$ & $75.00 \mathbf{4}$ & $-15.49 \downarrow$ & $12.385 \downarrow$ \\
\hline$\%$ Change & $-65.52 \downarrow$ & $-65.05 \downarrow$ & $-25.62 \downarrow$ & $-13.45 \downarrow$ & $20.57 \boldsymbol{\uparrow}$ & $21.28 \boldsymbol{\uparrow}$ \\
\hline \multicolumn{7}{|l|}{$\begin{array}{l}\text { Group III SLE } \\
\text { Before treatment }\end{array}$} \\
\hline mean \pm SD & $11.40 \pm 2.16^{\mathrm{a}}$ & $18.2 \pm 10.43^{\mathrm{a}}$ & $40.00 \pm 18.35^{\mathrm{a}}$ & $66.50 \pm 15.14^{\mathrm{a}}$ & $37.85 \pm 16.95^{\mathrm{a}}$ & $14.55 \pm 2.78^{\mathrm{a}}$ \\
\hline Range & $(8.00-14)$ & $(6.00-35.00)$ & $(20.00-80.00)$ & $(40.00-80.0)$ & $(18.00-65.00)$ & $(9.00-18.00)$ \\
\hline *\% Change & $171.43 \boldsymbol{4}$ & 833.33 个 & 952.63 个 & 877.27 个 & $-67.51 \downarrow$ & $-55.50 \downarrow$ \\
\hline \multicolumn{7}{|l|}{ After treatment } \\
\hline mean \pm SD & $10.80 \pm 6.03^{\mathrm{ab}}$ & $7.20 \pm 3.14^{\mathrm{ab}}$ & $16.50 \pm 4.89^{\mathrm{ab}}$ & $23.40 \pm 9.77^{\mathrm{ab}}$ & $76.55 \pm 19.18^{\mathrm{ab}}$ & $23.90 \pm 3.32^{\mathrm{ab}}$ \\
\hline Range & $(4.00-24.00)$ & $(4.00-16.00)$ & $(10.00-20.00)$ & $(8.00-40.00)$ & $(50-140)$ & $(18.00-33.00)$ \\
\hline *\% Change & $157.14 \mathbf{4}$ & $269.23 \boldsymbol{\uparrow}$ & $334.21 \boldsymbol{4}$ & $244.12 \boldsymbol{\uparrow}$ & $-34.29 \downarrow$ & $-26.91 \downarrow$ \\
\hline${ }^{* *} \%$ Change & $-5.26 \downarrow$ & $-62.3 \downarrow$ & $-58.75 \downarrow$ & $-66.57 \downarrow$ & $102.24 \mathbf{4}$ & $64.26 \mathbf{4}$ \\
\hline
\end{tabular}

Each value is considered statistically significant at $p<0.001 .{ }^{*} \%$ Change from the control group; ${ }^{* *} \%$ Change from the untreated groups; ${ }^{2}$ Patients groups significantly different from control group; ${ }^{b}$ Patients groups before therapy significantly different from Patients groups after immunotherapy.

where they found that $\mathrm{Sp}$. IgE antibodies can be used for diagnosis, prognosis, and follow up of patients with allergy-like symptoms and that high levels of casein-s IgE antibodies are strongly associated with milk allergy in children and might be associated with prolonged allergy. Also [4] found that the elevation of total IgE as a result of allergy may be due to extrinsic factors which increase the concentration of allergic antibodies of total $\operatorname{IgE}$, leading to increase the severity of allergy. Furthermore a significant $(p<0.001)$ positive correlation was observed in the present results $(r=0.77)$ between specific IgE and total IgE suggested that a pattern of allergen-specific $\operatorname{IgE}$ sensitization occurs in relation to total IgE concentration as reported by [27]. Also in the current results (Table 2, Gr11) the highly elevated levels of RF as compared to the control group confirmed the diagnosis of RA as reported by [28]. Lower levels of $\operatorname{IgG}$ in the RA group before therapy than that of the control group clinically consider to be indicative of an individual's immune status as stated by [29]. The observed significant decrease in the mean PIT \% in RA group when compared to the control group was in agreement with [30] who reported an inflammation by histamine which inhibits the phagocytosis, and leads to reduction in immunoresistant. In the same time the observed significant elevations in the mean CRP levels before therapy in RA group (Table 2), as compared to the control group indicates high degree of inflammation which in accordance with [28,31] who reported that CRP is a member of the class of acute-phase reactants, as its levels rise dramatically dur- 
Table 3. Correlations between Sp. IgE and each parameter in the different studied groups.

\begin{tabular}{ccccccccccc}
\hline & $\begin{array}{c}\text { Total } \\
\text { IgE }\end{array}$ & IgG & $\begin{array}{c}\text { PIT } \\
\text { \% }\end{array}$ & RF & CRP & ANA & $\begin{array}{c}\text { anti } \\
\text { DNA }\end{array}$ & C3 & C4 \\
\hline $\begin{array}{c}\text { Gr.I } \\
\text { control }\end{array}$ & 0.19 & 0.07 & -0.30 & 0.00 & 0.35 & -0.17 & 0.00 & 0.02 & 0.29 \\
$\begin{array}{c}\text { Gr.II } \\
\text { before }\end{array}$ & 0.77 & -0.74 & -0.78 & 0.33 & 0.34 & -0.04 & -0.33 & -0.02 & 0.34 \\
$\begin{array}{c}\text { Gr.II } \\
\text { After }\end{array}$ & 0.67 & -0.56 & -0.66 & -0.17 & 0.04 & -0.09 & -0.21 & 0.05 & 0.34 \\
$\begin{array}{c}\text { Gr.III } \\
\text { before }\end{array}$ & 0.37 & -0.73 & -0.80 & 0.10 & 0.76 & 0.72 & 0.61 & -0.61 & -0.23 \\
Gr.III & -0.04 & 0.18 & -0.52 & -0.36 & 0.74 & 0.03 & -0.02 & 0.05 & -0.44 \\
After & & & & & & & & & &
\end{tabular}

ing inflammatory processes occurring in the body. This increment is due to a rise in the plasma concentration of IL-6, which is produced predominantly by macrophages.

Regarding to the effect of OAIT on RA group it was found that it alleviated most of the changes in the above mentioned parameters. This was showed from the significant decrease in the levels of specific IgE and total $\mathrm{IgE}$ as compared to their pretreatment levels, in spite of being, still higher than control values which might be considered the first signs of an immunologic effect of the therapy and indicated a marked improvement in allergic severity as supported by [32,33]. Also it means improvement in clinical manifestation of allergic disorder $[25,34,35]$. The mean values of RF titers after therapy were significantly reduced indicating improvement in the severity of the disease as a result of the immunotherapy (Table 2). The effect was more obvious in the RA group than the SLE group which showed from the drastic decrease in the \% change to $-65.52 \%$ in post treated RA group. This was found to be in accordance with $[10,36]$. However, regarding the effect of therapy on IgG levels (Table 1), a significant increases was observed compared to the pretreated levels which means improvement in clinical manifestation due to blocking of IgE antibodies by IgG, alleviating the symptoms of allergy which agrees with the observations of $[37,38]$ reported that the induction of allergen-specific IgG antibodies has been identified as a major mechanism responsible for the reduction of allergic inflammation in allergic patients treated by antigen-SIT. In addition, passive administration of blocking antibodies may be considered as a potential therapeutic strategy for allergic diseases. As for the effect of immunotherapy on PIT, the data obtained (Table 1) showed that there was a significant improvement in the mean PIT levels after therapy as compared to that before therapy however, it was still lower than that of the normal control levels which reflects an improved clinical outcome of allergic patients as suggested by [39]. The mean values of CRP after immunotherapy were significantly reduced as compared to their respective untreated values (Table 2) which was in agreement with [40] who reported that CRP concentration is an important prognostic factor of many acute and chronic diseases and that serial CRP measurement may be useful to reflect a patient's response to therapy that aims to modify the underlying inflammatory process.

Concerning SLE group of patients before OAIT as compared to the control group (Table 1 Gr.111) it was found that the changes in the levels of Sp. IgE, total IgE, IgG, PIT and CRP are more or less similar to that of RA group of patients which confirmed the diagnosis of milk allergen and the severity of allergy due to milk allergen in addition to a degree of inflammation. Elevated serum $\operatorname{IgE}$ has been described in SLE and a direct association was found between total IgE and SLE overall or with other disease characteristics after adjusting for demographic characteristics and allergy history as reported by [41]. Regarding the elevation in the levels of RF in SLE group of patients (Table 2), it was found to be less obvious in SLE group of patients than that in RA group compared to the control group which in accordance with [42]. The elevation in CRP in this group of patients was found to be in contrary to that reported by [28] who declared that SLE failed to elicit major CRP production despite evident inflammation and tissue damage and the reason was not known. However, in accordance with the current results, [43] reported elevations of serum CRP during the course of SLE illness. ANAs are autoantibodies directed against contents of the cell nucleus and it is the primary laboratory test used to diagnose SLE [44]. Anti-ds DNA antibodies are a group of anti-nuclear antibodies and their target antigen is double stranded DNA, they are incredibly specific for SLE. It was highly correlated with disease activity in most patients [30] and it is considered the best single parameter for predicting active SLE [45]. Accordingly elevation in the values of ANA and anti-ds DNA in SLE patients as compared to the control group confirmed the diagnosis of SLE. The increase in the levels of ANA and anti-ds DNA was also observed in RA but to lesser extent confirming that these parameters are more specific for SLE group than RA group. This is in agreement with the results of [46] who reported that the elevation of the ANA titer to 1:40 or higher is the most sensitive of the American College of Rheumatology (ACR) diagnostic criteria for SLE, also more than 99\% of patients with SLE have an elevated ANA titer. Complement tests, most commonly $\mathrm{C} 3$ and $\mathrm{C} 4$, may be used to help diagnose and monitor the activity of acute or chronic autoimmune diseases such as SLE [47]. The significant decrease in the mean levels of $\mathrm{C} 3 \& \mathrm{C} 4$ before therapy was more pronounced in SLE group than RA group compared to control as showed from the $\%$ change 
values which was -67.51 for SLE and -29.91 for RA. The complements deficiencies insure the diagnosis of SLE group and agreed with the results of $[45,48]$ which indicated that $\mathrm{C} 3, \mathrm{C} 4$ concentrations were lower in the active stage of SLE and reported that association between complement deficiencies and SLE supports an important role of complement in preventing immune complex mediated tissue damage. Previously it was reported that abnormal levels of $\mathrm{C} 4 \mathrm{~d}$ reflecting disease activity in SLE [49].

Concerning the effect of OAIT on SLE group it was found that it greatly attenuated most of the parameters under study. This is indicated from the significant decrease in the levels of $\mathrm{Sp}$. IgE, total IgE, and the significant increase in the levels of IgG, and PIT\% as compared with their pretreated levels which showed an enhancement in the severity of allergy, improvement of immune system and reduction of allergic inflammation. From the present results (Table 2) it was observed that the mean values of ANA after immunotherapy was found to be greatly reduced in SLE group as compared with the pretreated values and this reduction was found to be more obvious than that in RA group. Therefore immunotherapy was more effective in alleviating the disease activity in the SLE group than the RA group. The mean values of anti-ds DNA after therapy in SLE group were also significantly decreased indicating a frank improvement in disease outcome. These results were in agreement with that reported by $[12,30]$ who declared that higher titres of anti-ds DNA antibodies are more suggestive of SLE and lower titres can be found in people without the disease. The mean C3, C4 levels after therapy were elevated as compared to the untreated levels however, these elevations were more pronounced in SLE group indicating a significant improvement in immuno-resistant disease activity and control the disease which in agreement with the results of $[48,49]$.

\section{Conclusion}

Efficacy of the immunotherapy was noticed from the reduction in the levels $\mathrm{Sp}$. IgE, total IgE, CRP, ANA, Anti-ds DNA and RF titre, and from the elevations in the levels of IgG, PIT, C3 and C4 in both groups of patients. However, more pronounced immunotherapy improvement was observed in SLE group than the RA group. So, milk desensitization is a valuable addition for the treatment of autoimmune conditions in Egypt. It is exceptionally safe, offers convenience for the patient.

\section{REFERENCES}

[1] H. Y. Lam, E. van Hoffen, A. Michelsen, K. Guikers, C. H. van der Tas, C. A. Bruijnzeel-Koomen and A. C.
Knulst, "Cow's Milk Allergy in Adults Is Rare but severe: Both Casein and Whey Proteins Are Involved," Clinical and Experimental Allergy, Vol. 36, No. 38, 2008, pp. 995-1002.

[2] S. H. Sicherer, "Food Allergy," The Mount Sinai Journal of Medicine, Vol. 78, No. 5, 2011, pp. 683-696. doi: $10.1002 / \mathrm{msj} .20292$

[3] J. M. Wal, "Bovine Milk Allergenicity," Annals Allergy Asthma \& Immunology, Vol. 93, No. 5, 2004, pp. S2-S11. doi:10.1016/S1081-1206(10)61726-7

[4] P. Restani, C. Ballabio and C. Lorenzo, "Molecular Aspects of Milk Allergens and Their Role in Clinical Events," Analytical and Bioanalytical Chemistry, Vol. 395, No. 1, 2009, pp. 47-56.

[5] G. A. Lied, K. Lillestøl, J. Valeur and A. Berstad, "Intestinal B Cell-Activating Factor: An Indicator of NonIgE-Mediated Hypersensitivity Reactions to Food?" Alimentary Pharmacology \& Therapeutics, Vol. 32, No. 2, 2010, pp. 66-73. doi:10.1111/j.1365-2036.2010.04314.x

[6] B. Schouten, B. C. A. M. Van Esch and A. O. J. Van Thuijl, "Contribution of IgE and Immunoglobulin Free Light Chain in the Allergic Reaction to Cow's Milk Proteins," Journal Allergy Clinical Immunology, Vol. 125, No. 2, 2010, pp. 1308-1314. doi:10.1016/j.jaci.2010.02.039

[7] S. H. Sicherer, "Food Allergy: When and How to Perform Oral Food Challenges," Pediatric Allergy Immunology, Vol. 10, No. 3, 1999, pp. 226-234. doi:10.1034/j.1399-3038.1999.00040.x

[8] I. M. Roitt, J. Brostoff and D. K. Male, "Immunology," 4th Edition, Gower Medical Publishing Ltd., London, 1996, pp. 150-640.

[9] N. Wegner, K. Lundberg and A. Kinloch, "Autoimmunity to Specific Citrullinated Proteins Gives the First Clues to the Etiology of Rheumatoid Arthritis," Immunological Reviews, Vol. 233, No. 3, 2010, pp. 34-54. doi:10.1111/j.0105-2896.2009.00850.x

[10] S. Karatay, T. Erdem and K. Yildirim, "The Effect of Individualized Diet Challenges Consisting of Allergenic Foods on TNF-Alpha and IL-1Beta Levels in Patients with Rheumatoid Arthritis," Rheumatology, Vol. 43, No. 11, 2004, pp. 1429-1433.

[11] A. Martorell, A. M. Plaza, J. Boné, S. Nevot, M. C. Gar-cía Ara, L. Echeverria, E. Alonso, J. Garde, B. Vila, M. Alvaro, E. Tauler, V. Hernando and M. Fernández, "Cow's Milk Protein Allergy. A Multi-Centre Study: Clinical and Epidemiological Aspects," Allergology and Immunopathology, Vol. 34, No. 2, 2006, pp. 46-53.

[12] E. Mortensen, K. Fenton and O. Rekvig, "Lupus Nephritis: The Central Role of Nucleosomes Revealed," American Journal Pathology, Vol. 172, No. 2, 2008, pp. 275283. doi:10.2353/ajpath.2008.070563

[13] R. Asero, G. Mistrello and R. Ariano, "Is Oral Immunotherapy the Cure for Food Allergies?" Current Opinion in Allergy and Clinical Immunology, Vol. 10, No. 2, 2010, pp. 214-219.

[14] A. J. Frew, “Allergen Immunotherapy," Journal Allergy 
Clinical Immunology, Vol. 125, No. 2, 2010, pp. 306-313. doi:10.1016/i.jaci.2009.10.064

[15] J. Antunes, L. Borrego, A. Romeira and P. Pinto, "Skin Prick Tests and Allergy Diagnosis," Allergologia et Immunopathologia, Vol. 37, No. 3, 2009, pp. 155-164. doi:10.1016/S0301-0546(09)71728-8

[16] A. S. El Shami and O. Alaba, "Liquid-Phase in Vitro Allergen-Specific IgE Assay with in Situ Immobilization," Advanced Bioscience, Vol. 74, No. 3, 1989, pp. 191-201.

[17] C. Pecquet, "IgE-Mediated Allergy to Latex 80 Patients," The 15th European Congress of Allergology and Clinical Immunology, Paris, 12 May 1992, pp. 1805-1812.

[18] T. M. Li, T. Chuang, S. Tse, D. Hovanec-Burns, A. S. El Shami, "Development and Validation of a Third Generation Allergen-Specific IgE Assay on the Continuous Random Access IMMULITE 2000 Analyzer," Annals of Clinical and Laboratory Science, Vol. 34, No. 1, 2004, pp. 67-74.

[19] R. Verbruggen, "Subtilopeptidase A Isoenzyme System. Interaction with Serum Components and Its Importance for Quantitative Immnoelectrophoresis," Biochemistrical Journal, Vol. 151, No. 1, 1975, pp. 149-155.

[20] K. L. Bandilla and F. C. Mc Duffie, "Latex Agglutination Slide Test for Quantitative and Semi Quantitative Determination of Rheumatoid Factors in Non-Diluted (ND) Serum," Journal Arithritis Rheumatism, Vol. 2, No. 1, 2009, pp. 12, 74.

[21] S. P. Ballou and I. Kushner, "C-Reactive Protein and the Acute Phase Response," Advances in Internal Medicine, Vol. 37, No. 2, 1992, pp. 313-336.

[22] D. E. Soliman and M. Yousef, "Specific Phagocytic Inhibition Test (A New Assay) in Diagnosis of Foods, Aspirin and Inhalants Allergy," Azhar Collaege Journal Azhar Medicine Faculty (Girls), Vol. 28, No. 3, 2007, pp. 559575.

[23] K. Egerer, D. Roggenbuck and R. Hiemann, “Automated Evaluation of Autoantibodies on Human Epithelial-2 Cells as an Approach to Standardize Cell-Based Immunofluorescence Tests," Arthritis Research \& Therapy, Vol. 12, No. 40, 2010, p. R40.

[24] H. Scott, S. Sampson and A. Hugh, "Food Allergy [Miscellaneous]," Journal of Allergy \& Clinical Immunology, Vol. 125, No. 2, 2010, pp. 116-125.

[25] R. Kumar, B. P. Singh and P. Srivastava, "Relevance of Serum IgE Estimation in Allergic Bronchial Asthma with Special Reference to Food Allergy," Journal of Allergy and Immunology, Vol. 24, No. 2, 2006, pp. 191-199.

[26] I. Sekigawa, Y. Tokano, T. Yoshiike, N. Iida, H. Hashimoto and H. Ogawa, "Relationship between Serum IgE and Autoantibody Levels in SLE Patients," Clinical Experimental Rheumatology, Vol. 21, No. 2, 2003, p. 683.

[27] K. R. Krishnan, E. L. Peterson and G. Wegienka, "Pattern of Allergen-Specific IgE Sensitization Relative to Total Serum Ig Concentration in Young Adults," Annals of Allergy, Asthma \& Immunology, Vol. 105, No. 5, 2010, pp. 401-403. doi:10.1016/j.anai.2010.09.014
[28] M. B. Pepysand and G. M. Hirschfield, "C-Reactive Protein: A Critical Update," Journal of Clinical Investigations, Vol. 111, No. 112, 2003, pp. 1805-1812.

[29] D. L. Mallery, W. A. McEwan and S. R. Bidgood, “Antibodies Mediate Intracellular Immunity through Tripartite Motif-Containing 21(TRIM21)," Proceedings of the National Academy of Sciences of the USA, Vol. 107, No. 46, 2010, pp. 19985-19990.

doi:10.1073/pnas.1014074107

[30] J. M. Skripak, E.C. Matsui, K. Mudd and R. A. Wood, "The Natural History of IgE-Mediated Cow's Milk Allergy," Journal of Allergy and Clinical Immunollogy, Vol. 120, No. 2, 2007, pp. 1172-1177.

[31] S. Black, I. Kushner and D. Samols, "C-Reactive Protein," Journal of Biological Chemistry, Vol. 279, No. 3, 2004, pp. 48487-48490. doi:10.1074/jbc.R400025200

[32] K. Bidad, M. H. Nicknam and R. Farid, "A Review of Allergy and Allergen Specific Immunotherapy," Iranian Journal of Allergy, Asthma and Immunology, Vol. 10, No. 1, 2011, pp. 1-9.

[33] C. Garcia-Ara, T. Byano-Martinez and J. M. Diaz-Pena, "Specific IgE Levels in the Diagnosis of Immediate Hypersensitivity to Cow's Milk Protein in the Infants," Journal of Allergy Clinical Immunology, Vol. 107, No. 1, 2001, pp. 185-190. doi:10.1067/mai.2001.111592

[34] E. Hidvegi, E. Cserhati, E. Kereki and E. Savilahti, "Serum Immunoglobulin E, IgA, and IgG Antibodies to Different Cow's Milk Proteins in Children with Cow's Milk Allergy: Association with Prognosis and Clinical Manifestations," Pediatric Allergy Immunology, Vol. 13, No. 4, 2002, pp. 255-261. doi:10.1034/j.1399-3038.2002.01045.x

[35] A. Douglass Jo and E. R. O'Hehir, "Diagnosis, Treatment and Prevention of Allergic Disease: The Basics," Medical Journal Australia, Vol. 185, No. 4, 2006, pp. 228-233.

[36] A. M. Atta, C. P. Sousa, E. M. Carvalho and M. L. SousaAtta, "Immunoglobulin E and Systemic Lupus Erythematosus," Brazil Journal of Medical Biology Research, Vol. 37, No. 10, 2004, pp. 1497-1501.

[37] S. Flicker and R. Valenta, "Renaissance of the Blocking Antibody Concept in Type I Allergy," International Archives of Allergy and Immunology, Vol. 132, No. 1, 2003, pp. 13-24. doi:10.1159/000073260

[38] S. Flicker, E. Gadermaier, C. Madritsch and R. Valenta, "Passive Immunization with Allergen-Specific Antibodies," Current Topics in Microbiology and Immunology, Vol. 3535, No. 2, 2011, pp. 141-159. doi: $10.1007 / 82 \quad 2011 \quad 143$

[39] I. A. Emanuel, M. J. Parker and O. Traub, "Under Treatment of Allergy: Exploring the Utility of Sublingual Immunotherapy," Otolaryngology-Head Neck Surgery, Vol. 140, No. 2, 2009, pp. 615-621. doi:10.1016/j.otohns.2009.01.023

[40] K. M. Ho and J. Lipman, "An Update on C-Reactive Protein for Intensives," Anaesthesia and Intensive Care Journal, Vol. 37, No. 2, 2009, pp. 234-241.

[41] C. G. Parks, R. E. Biagini, G. S. Cooper, "Total Serum 
IgE Levels in Systemic Lupus Erythematosus and Associations with Childhood Onset Allergies," Lupus Journal, Vol. 19, No. 5, 2010, pp. 1614-1622. doi:10.1177/0961203310379870

[42] J. Smolen, "Rheumatoid Arthritis," In: R. N. Maini and W. J. van Venrooij, Eds., Manual of Biological Markers of Disease, Kluwer Academic Publishers, Amsterdam, 1996, pp. 1-18. doi:10.1007/978-94-011-1670-1 37

[43] R. C. Williams, M. E. Harmon, R. Burlingame and T. W. Du Clos, "Studies of Serum C-Reactive Protein in Systemic Lupus Erythematosus," Journal Rheumatology, Vol. 32, No. 3, 2005, pp. 454-461.

[44] J. M. Gill, A. M. Quisel, P. V. Rocca and D. T. Walters, "Diagnosis of Systemic Lupus Erythematosus," American Family Physician, Vol. 68, No. 5, 2003, p. 2179.

[45] C. K. Ting and K. A Hsieh, "A Long-Term Immunological Study of Childhood Onset Systemic Lupus Erythematosus," Annuals of the Rheumatic Diseases, Vol. 51, No. 1, 1992, pp. 45-51.
[46] I. Gilboe and G. Husby, "Application of the 1982 Revised Criteria for the Classification of Systemic Lupus Erythematosus on a Cohort of 346 Norwegian Patients with Connective Tissue Disease," Scandinavian Journal of Rheumatology, Vol. 28, No. 2, 1999, pp. 81-87. doi:10.1080/030097499442531

[47] J. M. Esdaile, L. Joseph and M. Abrahamowicz, "Routine Immunologic Tests in Systemic Lupus Erythematosus: Is There a Need for More Studies?" The Journal of Rheumatology, Vol. 23, No. 11, 1996, pp. 1891-1896.

[48] N. Hussain, G. Jaffery and S. Hasnain, "Serum Complement C3 and C4 Levels in Relation to Diagnosis of Lupus Nephritis," Tropical Journal of Pharmaceutical Research, Vol. 7, No. 4, 2008, pp. 1117-1121.

[49] C. C. Liu, S. Manzi and A. H. Kao, "Reticulocytes Bearing C4d as Biomarkers of Disease Activity for Systemic lupus Erythematosus," Arthritis \& Rheumatism, Vol. 52, No. 10, 2005, pp. 3087-3099. doi:10.1002/art.21305 